\title{
Rapid Field and
}

Laboratory Method for

the Determination of

Copper in Soil and Rocks

GEOLOGICAL SURVEY BULLETIN 1036 -A

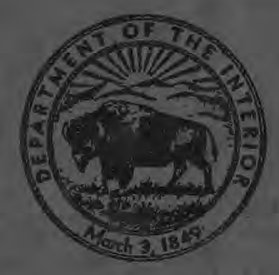




\section{Rapid Field and}

Laboratory Method for the Determination of

\section{Copper in Soil and Rocks}

By HY ALMOND

A CONTRIBUTION TO GEOCHEMISTRY

GE O L O I C A L S U R V E Y B U L L E T N $1036-\mathrm{A}$

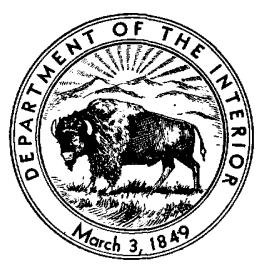


UNITED STATES DEPARTMENT OF THE INTERIOR

Douglas McKay, Secretary

GEOLOGICAL SURVEY

W. E. Wrather, Director 


\section{CONTENTS}

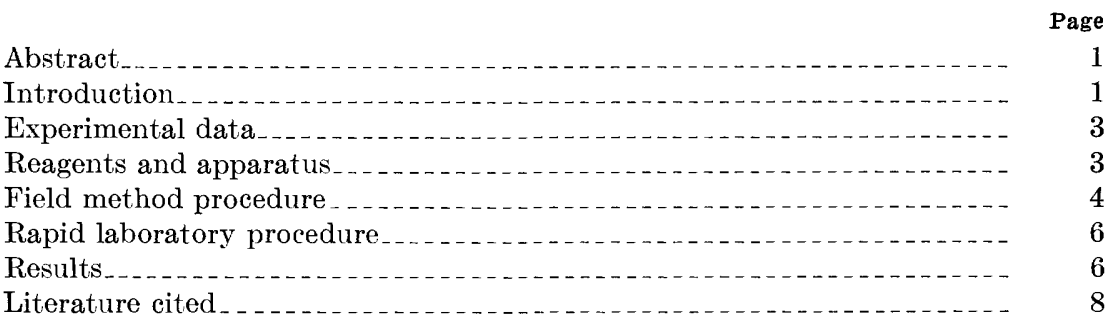

\section{ILLUSTRATION}

Figure 1. Digestion and fusion rack shown with a gasoline stove and covers 



\title{
A CONTRIBUTION TO GEOCHEMISTRY
}

\section{RAPID FIELD AND LABORATORY METHOD FOR THE DETERMINATION OF GOPPER IN SOIL AND ROGKS}

\author{
By Hy Almond
}

\begin{abstract}
A rapid method for the determination of traces of copper in soils and rocks under field conditions and in the laboratory involves fusion of the sample with potassium bisulfate and estimation of copper with biquinoline in an isoamyl alcohoi extract. The method is useful for prospecting and for gathering basic geochemical data. Only simple equipmnt is needed in the field. Because the reagent and copper complex are stable, the standard series for visual colorimetric estimation are prepared about once a month. The method is simple and about 60 to 80 determinations can be made per man-day under field conditions.
\end{abstract}

\section{INTRODUCTION}

Colorimetric reagents are used by the U. S. Geological Survey to estimate the trace-element content of various soils, rocks, and other natural materials. The data collected aid in formulating basic geochemical principles and in prospecting. Until recently the reagents commonly used for the determination of copper have been diphenylthiocarbazone (dithizone), sodium diethyldithiocarbamate, and rubeanic acid, but each of these reagents has undesirable properties. Estimation of copper with dithizone, as described by Lovering, Huff, and Almond (1950), requires careful adjustment of the acidity of the solution to a $\mathrm{pH}$ of about 3 . A lower $\mathrm{pH}$ requires shaking for more than 2 minutes to extract the copper; a higher $\mathrm{pH}$ results in interference from zinc. Oxidation of dithizone by sunlight or by ferric iron also causes difficulties (Sandell, 1950). Sodium diethyldithiocarbamate also has properties that are undersirable. Iron interferes unless properly complexed and even in the presence of large amounts of citrate, bismuth will invariably react with sodium diethyldithiocarbamate. This reagent must be freshly prepared because it may decompose to impart yellow products in the organic solvent that are 
reported as copper. Rubeanic acid has been used in the Geological Survey's laboratory in Denver, Colo. as a confined spot test reagent for the determination of copper with the chromograph (Stevens and Lakin, 1949). This equipment must be kept in good working order to give accurate results, but proper maintenance of the chromograph is difficult under field conditions. The determination of copper with rubeanic acid by solution colorimetry is underisable because the complex is insuluble and, as far as known, nonextractable with organic solvents.

Breckenridge, Lewis, and Quick (1939) report that the reaction of copper (I) with biquinoline is specific for copper. Hoste (1950) states that biquinoline is superior to dithizone as a reagent for the determination of copper. A spectrophotometric method for the determination of coper with cuproine (biquinoline) is described by Hoste, Eeckhout and Gillis (1953). The determination was made on many kinds of material. Cheng and Bray (1953) used the reagent to determine copper in soils. They found that the copper complex is extractable into isoamyl alcohol with a maximum absorption at $540 \mathrm{~m} \mu$. Studies carried out by Cheng and Bray indicate interference from the following: citrate, concentrated ammonium hydroxide, ethylenediaminetetraacetate, oxalate, cyanide, thiosulfate, soluble silicate, bromate, iodate, ferricyanide, and cyanate.

By modifying the technique for sample decomposition and by using the standard-series method of estimation, biquinoline reagent was found to be suitable for the determination of traces of copper in soils and rocks under field conditions. The biquinoline method, as a field method for the determination of copper, has five distinct advantages over the dithizone method: (1) the $\mathrm{pH}$ of the aliquot taken is more easily adjusted, (2) the time that the buffered solution needs to be shaken with reagent is less, (3) the reagent is specific for copper, (4) the reagent and complex are more stable, and (5) the standard series has a greater range.

The rapid laboratory method and its field adaptation, both using biquinoline, are described below. A pyrosulfate fusion of a powdered soil or rock sample, followed by extraction into hydrochloric acid, dissolves essentially all of the copper. Neither sulfate nor chloride interfere with the biquinoline method, so this treatment is suitable for dissolving copper from soil or rock. Hydroxylamine is added to an aliquot to reduce copper (II) to copper (I), tartrate to complex iron and aluminum, and acetate to buffer the solution. The copper biquinoline complex is then extracted into isoamyl alcohol. Field and laboratory techniques differ only in that, in the former field stoves are used rather than Bunsen or Fischer burners, measurement of 
volumes is approximate rather than exact, and estimations are made by comparison with a standard series rather than instrumentally.

\section{EXPERIMENTAL DATA}

The fusion with potassium bisulfate followed by extraction with hydrochloric acid dissolves copper in soils and rocks. The final acidity of the hydrochloric acid solution has to be such that on standing overnight the copper content of the solution will be the same as the copper content of the freshly prepared solution, because frequently the copper in samples is decomposed in the late afternoon of one work day and aliquots for estimation are not taken until the next morning. Replicates of a sample in $0.3 \mathrm{~N}$ hydrochloric acid analyzed within one hour after dissolving the copper and replicates of a sample analyzed after standing overnight show the result of too low an acidity as follows:

Copper content, in parts per million

$\begin{array}{cc}1 \text { Hour } & \text { Standing overnight } \\ 40 & 8 \\ 36 & 6 \\ 37 & 16 \\ 37 & 8 \\ & 7\end{array}$

As can be seen, a significant loss takes place on standing overnight in this weakly acid solution. For this reason the extraction of the bisulfate melt is done with $3 \mathrm{ml}$ of $6 \mathrm{~N}$ hydrochloric acid, which is then diluted to $10 \mathrm{ml}$ with water. No losses of copper were detected when using this more acid solution in repeating the above experiment.

The use of a fixed volume of buffer to eliminate titration to a given $\mathrm{pH}$ is a timesaving step especially important for field analyses. An experiment was made to determine the amount of buffer needed per aliquot of test solution. One gram of potassium bisulfate was fused to a clear melt, cooled, dissolved in $4 \mathrm{ml}$ of $(1+1)$ hydrochloric acid, and then diluted to $10 \mathrm{ml}$ with water. Five milliliters of this solution with $10 \mathrm{ml}$ of the buffer solution, described later, resulted in a solution of $\mathrm{pH} 4.4$, a proper $\mathrm{pH}$ for the test. In the procedure, $10 \mathrm{ml}$ of buffer is recommended to $2.5 \mathrm{ml}$ of sample solution, allowing a considerable safety factor for variation of the acidity of the solution before the addition of the buffer.

\section{REAGENTS AND APPARATUS}

All reagents listed are analytical grade. Items needed for field use only are preceded by an asterisk (*), those needed for laboratory use only are preceded by two asterisks $(* *)$. 
Biquinoline $(0.02$ percent, $\mathrm{W} / \mathrm{V})$. Dissolve 0.2 gram of $2,2^{\prime}$-biquinoline in $900 \mathrm{ml}$ isoamyl alcohol by warming in a beaker on a hot plate. Cool, make up to 1 liter with isoamyl alcohol in a 1-liter volumetric fiask. The reagent in isoamyl alcohol should be colorless. If the solution is yellow, the reagent is impure and should not be used.

Buffer solution. Dissolve 400 grams of sodium acetate and 100 grams of sodium potassium tartrate in 1 liter of water. To $10 \mathrm{ml}$ of the solution in a screw-cap culture tube add about $50 \mathrm{mg}$ hydroxylamine hydrochloride, mix to dissolve, then add $1 \mathrm{ml}$ of $2,2^{\prime}$-biquinoline reagent. Screw the cap in place and shake 2 minutes. If no pink appears in the organic phase, the buffer is free of copper contamination and is satisfactory for use in the procedure described.

Hydroxylamine hydrochloride.

Potassium pyrosulfate.

Hydrochloric acid $(1+1)$. Add $500 \mathrm{ml}$ of concentrated hydrochloric acid to $500 \mathrm{ml}$ of metal-free water.

Standard copper solution 0.01 percent. Dissolve 0.2 gram of clear uneffloresced crystals of $\mathrm{CuSO}_{4} \cdot 5 \mathrm{H}_{2} \mathrm{O}$ in water, add $70 \mathrm{ml}$ of concentrated hydrochloric acid, then dilute to $500 \mathrm{ml}$ with water. One milliliter contains 100 micrograms of copper. Prepare more dilute solutions from this solution.

Culture tubes, $16 \times 150 \mathrm{~mm}$, borosilicate, marked at 3 and $10 \mathrm{ml}$.

Resin demineralizer. Pass stream water or tap water through a resin demineralizer to free it of heavy metals.

Sieve, 100-mesh sieve made of noncontaminating material.

Mortar and pestle, to grind rock samples.

Torsion balance. Sensitivity to $2 \mathrm{mg}$ is satisfactory.

Pipets, serological; capacities $1.0 \mathrm{ml}$ and $5.0 \mathrm{ml}$, both graduated at $0.1 \mathrm{ml}$.

Pipet, volumetric, 10-ml capacity.

Test tube rack, to hold 30-50 culture tubes.

*Automatic pipet, 2-ml capacity. Any simple, commercially available one is satisfactory.

*Screw-cap culture tubes, $25 \times 100 \mathrm{~mm}$.

*Digestion and fusion rack. This piece of apparatus, shown in figure 1 , is used to support culture tubes over a gasoline stove. The rack consists of three disks of sheet steel $115 \mathrm{~mm}$ in diameter, welded to a central supporting rod $200 \mathrm{nmm}$ long. The upper and central disks have holes large enough for the culture tube to pass through. The lower disk has holes which are just small enough to prevent the culture tube from slipping through, but large enough to permit the ready flow of heat.

$* *$ Volumetric fiask, glass stoppered, $25 \mathrm{ml}$.

**Automatic buret, 25-ml capacity.

**Cotton, absorbent.

**Filter paper, Whatman no. 42, 1-cm diameter.

**Funnels, $50 \mathrm{~mm}$ diameter, $50 \mathrm{~mm}$ stem.

**Colorimeter or spectrophotometer. The Beckman, model B was used with Corex absorption cells at $10 \mathrm{~mm}$ light path. Any such instrument is satisfactory.

\section{FIELD METHOD PROCEDURE}

Place $0.1 \mathrm{~g}$ of minus-100-mesh soil or rock sample in a culture tube, add about $0.5 \mathrm{~g}$ potassium pyrosulfate, place in the fusion and digestion rack, and fuse over the gasoline stove (fig. 1) for several minutes. 


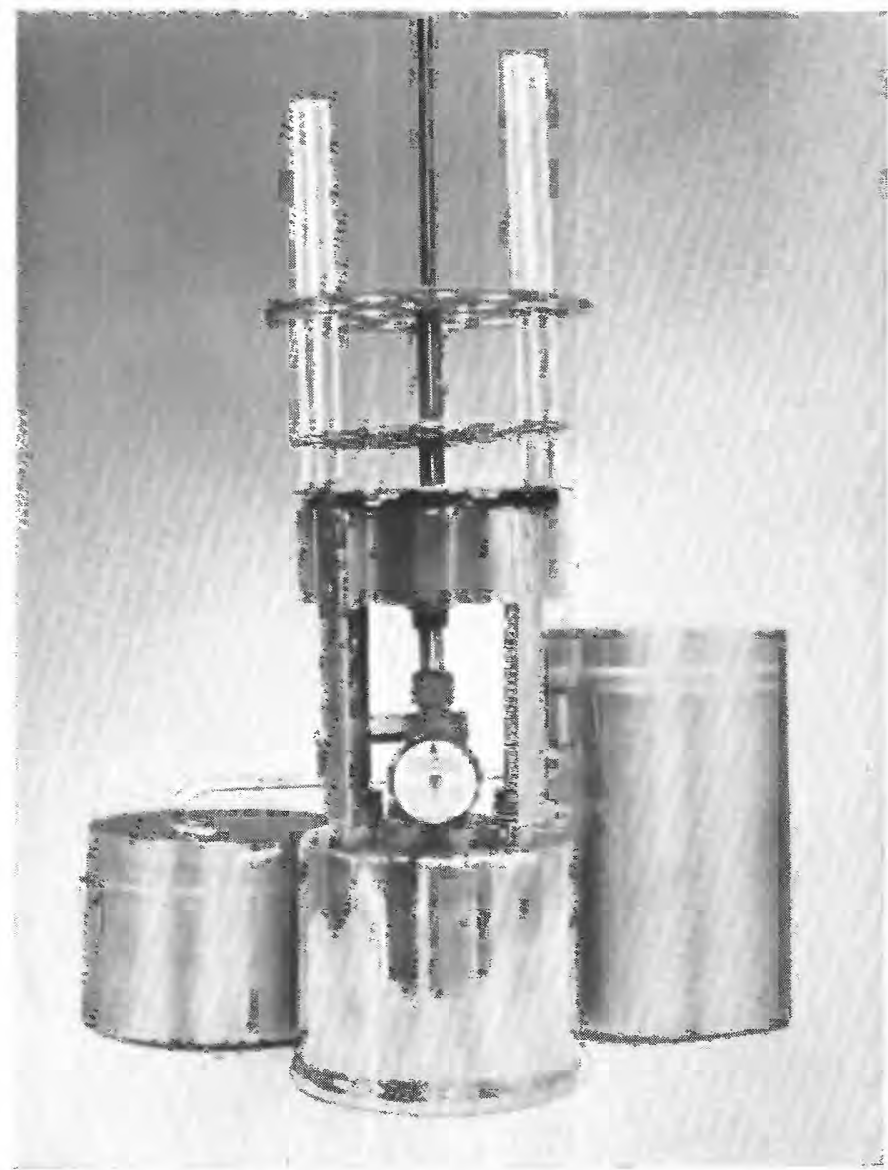

Figure 1.-Digestion and fusion rack shown with a gasoline stove and covers. The covers serve as hot-water baths.

Remove from heat, rotate the tube so that the melt solidifies in a thin layer on the walls of the tube, then cool and add $3 \mathrm{ml} 6 \mathrm{~N}$ hydrochloric acid. Add water to the smaller cover of the stove, and warm over the gasoline stove. Place the culture tube in the digestion and fusion rack, then place the entire rack in the water bath so that the culture tube is immersed in the hot-water bath. Allow to remain in the hot-water bath until the melt is broken up. Then remove and dilute to $10 \mathrm{ml}$. Mix the solution.

Transfer a 2.5-ml aliquot to a screw-cap culture tube, add about 50 $\mathrm{mg}$ of hydroxylamine hydrochloride, and allow to stand but shake occasionally until the hydroxylamine hydrochloride is dissolved. Add $10 \mathrm{ml}$ of buffer solution, then, using a plunger-type automatic pipet, add $2 \mathrm{ml}$ of isoamyl alcohol containing biquinoline. (Avoid getting 
reagent in the rubber bulb of the pipet as this may contain copper.) Screw a polyethylene cap on the culture tube, and shake the tube 30 seconds. Allow to stand about a minute or until the isoamyl alcohol phase separates, then compare with a copper biquinoline standard series.

Prepare copper standard series as follows: To a series of screw-cap culture tubes add standard copper solution equivalent to $0,0.2,0.4$, $0.7,1.0,1.5,2.5,4.0,7.0$, and 10 micrograms of copper. Dilute to about $5 \mathrm{ml}$ with water, add about $50 \mathrm{mg}$ of hydroxylamine hydrochloride, and proceed as in the previous paragraph. Loosen the polyethylene screw caps so that they do not freeze in place. New standards need be prepared not oftener than once a month.

\section{RAPID LABORATORY PROCEDURE}

Place $0.2 \mathrm{~g}$ minus-100-mesh soil or rock sample in a culture tube, add $1.0 \mathrm{~g}$ of potassium pyrosulfate, and fuse. Remove from the flame and rotate the tube so that the melt solidifies in a thin layer on the tube. Add $4 \mathrm{ml} \mathrm{N}$ hydrochloric acid, place in a water bath, and digest until the melt is broken up. Filter into a $25-\mathrm{ml}$ volumetric flask. Wash with hot water. Dilute to volume with water. Mix. Carry out the estimation within an hour after dilution.

Transfer a 5-ml aliquot to a separatory funnel. Add about $50 \mathrm{mg}$ of hydroxylamine hydrochloride, then $10 \mathrm{ml}$ buffer solution. Add exactly $3 \mathrm{ml}$ of isoamyl alcohol containing biquinoline from an automatic buret. Stopper and shake for 1 minute. Allow the solution to stand for about 5 minutes. Drain and discard the inorganic phase. Add about $0.5 \mathrm{ml}$ water, shake, allow the layers to separate, and drain and discard the water. Insert a plug of absorbent cotton in the stem of the funnel. Drain the organic solvent into absorption cell, and determine the absorbance at $546 \mathrm{~m} \mu$.

\section{RESULTS}

The precision and accuracy of the field method were determined by analyzing 30 soil and rock samples by the carbamate laboratory method described by Holmes (1945). These samples were then analyzed by the field method in duplicate. The first 27 samples ranged from the highly silicic rocks to the basic rocks. With each fresh rock, the corresponding weathered rocks and overlying soils were analyzed. The results of the analyses are given below. 
Comparison of results by laboratory and field methods of analysis

\begin{tabular}{|c|c|c|}
\hline \multirow[b]{2}{*}{ Sample } & \multicolumn{2}{|c|}{$\begin{array}{l}\text { Copper content, in parts } \\
\text { million }\end{array}$} \\
\hline & $\begin{array}{l}\text { Laboratory } \\
\text { method } \\
\text { (carbamate) }\end{array}$ & $\begin{array}{c}\text { Field } \\
\text { method- } \\
\text { duplicates } \\
\text { (biquinoline) }\end{array}$ \\
\hline Castle Rock rhyolite, fresh_. & 3 & \\
\hline Weathered & 1 & 6,2 \\
\hline Soil $\ldots \ldots$ & 17 & 18,16 \\
\hline Silver Plume granite, fresh & 13 & 9,12 \\
\hline Weathered & 19 & 12,12 \\
\hline Soil & 17 & 20,24 \\
\hline 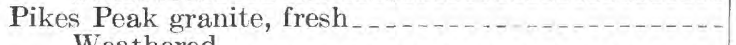 & 8 & 10,12 \\
\hline $\begin{array}{l}\text { Weathered } \\
\text { Soil }\end{array}$ & 10 & 8,13 \\
\hline $\begin{array}{l}\text { Soil } \\
\text { Boulder Creek granite, fresh }\end{array}$ & $\begin{array}{l}11 \\
38\end{array}$ & $\begin{array}{r}8,8 \\
40,36\end{array}$ \\
\hline Weathered & 9 & $\begin{array}{l}40,00 \\
36,20\end{array}$ \\
\hline Soil & 29 & 20,24 \\
\hline $\begin{array}{l}\text { Intermediate quartz monzonite (St. V rain Canyon), } \\
\text { fresh }\end{array}$ & 9 & 424 \\
\hline Weathered & $\begin{array}{r}9 \\
35\end{array}$ & $\begin{array}{r}4,24 \\
60,70\end{array}$ \\
\hline Soil _... & 21 & 24,24 \\
\hline Monzonite porphyry (Gold Hill), fresh & 10 & 6,3 \\
\hline Weathered & 9 & 8,4 \\
\hline Soil__ & 11 & 14,12 \\
\hline Diorite (Jamestown), fresh & 32 & 40,70 \\
\hline Weathered & 82 & 60,60 \\
\hline Soil $\ldots \ldots$ & 83 & 70,80 \\
\hline Basalt (Table Mountain), fresh & 65 & 60,60 \\
\hline Weathered $\ldots \ldots$ & 58 & 80,60 \\
\hline Basalt (Ralston Dike), fresh & $\begin{array}{l}45 \\
57\end{array}$ & $\begin{array}{l}40,50 \\
60,46\end{array}$ \\
\hline Weathered & 42 & 60,36 \\
\hline Soil $\ldots \ldots \ldots$ & 56 & 65,50 \\
\hline Eastern soil, composite $\mathrm{A}_{-}$ & 360 & 350 \\
\hline 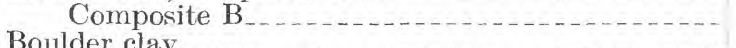 & 60 & 50 \\
\hline (n) & 30 & 20 \\
\hline
\end{tabular}

Youden (1951) expresses the confidence limits at the 95 percent levels as follows:

$$
\text { Confidence limit }=\mu \pm \frac{\mathrm{f} \sigma}{\sqrt{\mathrm{n}}}
$$

where

$$
\begin{aligned}
& \mu=\text { arithmetical average } \\
& \mathbf{f}=\text { factor of } 2.78 \text { for } 5 \text { replicates and } 3.18 \text { for } 4 \text { replicates } \\
& \sigma=\text { standard deviation } \\
& \mathrm{n}=\text { number of replicates }
\end{aligned}
$$


The 95 percent confidence level of the field method was examined by analyzing three samples by the field method 5 times and applying the results to the equation. The 95 percent confidence level of the rapid laboratory method was examined by analyzing the same three samples 4 times by the rapid laboratory method and again applying the results to the equation. The results are given below. The laboratory value is that value obtained by the analyses of the sample by the Holmes method where, after suitable separation, copper is estimated with sodium diethyldithiocarbamate.

Confidence limits at the 95 percent level for the field and the rapid laboratory methods compared with results obtained by an accepted laboratory procedure.

\begin{tabular}{|c|c|c|c|}
\hline \multirow[b]{2}{*}{ Sample number } & \multicolumn{3}{|c|}{ Copper content, in parts per million } \\
\hline & $\begin{array}{c}\text { Field } \\
\text { (biquinoline) }\end{array}$ & $\begin{array}{c}\text { Rapid } \\
\text { laboratory } \\
\text { (biquinoline) }\end{array}$ & $\begin{array}{l}\text { Laboratory } \\
\text { (carbamate) }\end{array}$ \\
\hline $\begin{array}{l}1 \ldots \ldots \\
2 \ldots \ldots \\
3 \ldots \ldots\end{array}$ & $\begin{array}{c}332 \pm 80 \\
39 \pm 12 \\
31 \pm 8.3\end{array}$ & $\begin{array}{l}325 \pm 33 \\
61 \pm 4.8 \\
38 \pm 3\end{array}$ & $\begin{array}{r}360 \\
60 \\
38\end{array}$ \\
\hline
\end{tabular}

\section{LITERATURE CITED}

Breckenridge, J. G., Lewis, R. W. J., and Quick, L. A., 1939, 2,2'-biquinoline, a reagent for copper: Canadian Jour. Research, v. 17, p. 258-265.

Cheng, Kuang Lu, and Bray, Roger H., 1953, Two specific methods of determining copper in soil and plant material: Anal. Chemistry, v. 25, p. 655-658.

Holmes, R. S., 1945, Determination of total copper, zinc, cobalt, and lead in soils and soil solutions: Soil Science, v. 59, p. 77-84.

Hoste, J., 1950, A new copper-specific group: Acta Anal. Chim., v. 4, p. 23-37.

Hoste, J., Eeckhout, J., and Gillis, J., 1953, Spectrophotometric determination of copper with cuproine: Acta Anal. Chim., v. 9, p. 263-274.

Lovering, T. S., Huff, L. C., and Almond, Hy, 1950, Dispersion of copper from the San Manuel copper deposit, Pinal County, Ariz.: Econ. Geology, v. 45, p. 493-514.

Sandell, E. B., 1950, Colorimetric determination of traces of metals, 2d ed., New York, Interscience Publishers, Inc., 673 p.

Stevens, R. E., and Lakin, H. W., 1949, The chromograph, a new analytical tool for laboratory and field use: U. S. Geol. Survey Circ. 63, p. 1-11.

Youden, W. J., 1951, Statistical methods for chemists, New York, John Wiley \& Sons, Inc., 126 p. 